\title{
Use of a New Enzyme Extraction System to Improve the Sensitivity of SOS/umu Test and Application to Environmental Samples
}

\author{
Zhe Tian $\cdot$ Yoshimitsu Oda $\cdot$ Yu Zhang $\cdot$ \\ Min Yang • Hongyan Li
}

Received: 14 February 2014/Accepted: 16 December 2014/Published online: 27 December 2014

(C) Springer Science+Business Media New York 2014

\begin{abstract}
The purpose of this study was to find a better enzyme extraction reagent for the SOS/umu test to replace the conventional one (the combination of sodium dodecyl sulfate (SDS) and Z-buffer), which has the disadvantage of denaturing $\beta$-galactosidase leading to decreased measurement sensitivity. By adopting a microplate system, the performance of the umu test using BugBuster Master Mix, a commercially available enzyme extraction reagent, was compared with that using the conventional reagent for detecting the genotoxicity of known mutagens as well as environmental samples. BugBuster Master Mix was found to increase the detection sensitivities of the selected genotoxins and environmental water samples, due to the fact that it doesn't denature $\beta$-galactosidase. The result of this study showed that BugBuster Master Mix could be a better enzyme extraction reagent for umu test.
\end{abstract}

Keywords SOS/umu test - $\beta$-Galactosidase activity · BugBuster Master Mix · Sodium dodecyl sulfate treatment $\cdot$ Genotoxicity

With increasing numbers of chemical substances being discharged into the environment, evaluation and monitoring of the impacts of these chemicals to the water environment and human health is becoming more and more important (Ohe et al. 2004). Rapid and sensitive bioassay systems have been developed for detecting environmental genotoxins as a whole based on the ability of these substances to cause DNA damage (Monarca et al. 2004).

Z. Tian $\cdot$ Y. Oda $\cdot$ Y. Zhang $(\bowtie) \cdot$ M. Yang $\cdot$ H. Li Key Laboratory of Drinking Water Science and Technology, Research Center for Eco-Environmental Sciences, Chinese Academy of Sciences, P.O. Box 2871, Beijing 100085, China e-mail: zhangyu@rcees.ac.cn
Among different bioassays for the detection of environmental mutagens, the SOS/umu test, which monitors the expression of one of the SOS genes (итиC gene) by measuring $\beta$-galactosidase activity (Oda et al. 1985), has attracted vast attention because of its simplicity, short test time and low requirement for disinfection (Hamer et al. 2000). By employing a single Salmonella typhimurium tester strain (S. typhimurium TA1535/pSK1002), this bioassay system allows the detection of SOS mutagenesis after treatment with DNA-damaging agents (Michel 2005). As the standardized method of ISO (ISO/CD 13829) (ISO 2000) and DIN (DIN 38415-3) (DIN 1996), the SOS/umu test has been extensively employed to detect genotoxicity in different media including airborne particles (Oda et al. 2004), tap water (Shen et al. 2003), reclaimed water (Wu et al. 2010) and industrial wastewater (Dizer et al. 2002).

Enzyme extraction is one of the important steps in the SOS/ ити test to detect the induced activity of $\beta$-galactosidase. In comparison with toluene, the frequently used protein extraction detergent, sodium dodecyl sulfate (SDS), demonstrated its advantage in shortening test time and increasing induced $\beta$ galactosidase activity (Whong et al. 1986), and the combination of SDS and Z-buffer (Miller 1972) has been widely used as the enzyme extraction system for the SOS/umu test. However, SDS treatment has been reported to denature $\beta$ galactosidase (Demeo et al. 1988; El Mzibri et al. 1996; Whong et al. 1986) and may result in poor protein recovery (De Mey et al. 2008), which can decrease the measurement sensitivity of $\beta$-galactosidase activity. As an effective protein extraction detergent, BugBuster Master Mix (B. M. Mix) is a specially formulated reagent combining BugBuster Protein Extraction Reagent with Benzonase ${ }^{\circledR}$ Nuclease and rLysozyme $^{\text {TM }}$ Solution (Novagen ${ }^{\circledR}$ and Calbiochem ${ }^{\circledR}$ 2004). The use of non-ionic detergents in BugBuster Protein Extraction Reagent permits cell wall perforation without denaturing 
target proteins, while the ability to hydrolyze $N$-acetylmuramide linkages in cell walls by rLysozyme ${ }^{\mathrm{TM}}$ Solution may enhance the extraction efficiency of soluble proteins, and the ability to degrade all forms of DNA and RNA by benzonase makes the resulting extract less viscous and more clarified, all of which are desirable features in a protein extraction reagent (Grabski et al. 1999; Novagen ${ }^{\circledR}$ and Calbiochem ${ }^{\circledR}$ 2006). Recently, Grage et al. (2011) has applied B. M. Mix to the assay of $\beta$-galactosidase to assess the functionality of purified recombinant protein. However, this reagent never was used for enzyme extraction in the uти test instead of the conventional system (the combination of SDS and Z-buffer).

In this paper, the applicability of B. M. Mix for the SOS/ ити test was evaluated by comparing its performance with that of the SDS-Z-buffer system in detecting the genotoxicity of some pure chemicals as well as a variety of environmental water samples. The results suggested that B. M. Mix, as an effective enzyme extraction reagent, could increase the sensitivity of the SOS/umu test.

\section{Materials and Methods}

The test chemicals were obtained from the following sources: 4-nitroquinoline 1-oxide (4-NQO), methyl methanesulfonate (MMS), 5-fluorouracil (5-FU), streptozotocin, 2 -aminoanthracene (2-AA) and benzo[ $\alpha]$ pyrene $(\mathrm{B}[\alpha] \mathrm{P})$ from Sigma-Aldrich (St. Louis, MO, USA); 2-amino-3methylimidazo[4,5-f]quinoline (IQ), 3-amino-1,4-dimethyl-5H-pyrido[4,3-b]indole (Trp-P-1) and 2-amino-1methyl-6-phenylimidazo[4,5- $b$ ]pyridine (PhIP) from Wako Pure Chemical Industries, Ltd. (Osaka, Japan); $N$-methyl$N^{\prime}$-nitro- $N$-nitrosoguanidine (MNNG) from Tokyo Chemical Industry Co., Ltd. (Tokyo, Japan). The enzyme substrate chlorophenol red- $\beta$-D-galactopyranoside (CPRG) was purchased from Sigma-Aldrich (St. Louis, MO, USA). BugBuster Master Mix (B. M. Mix in short) protein extraction reagent $\left(\right.$ Novagen ${ }^{\circledR}$ ) was obtained from EMD Chemicals, Inc. (San Diego, CA, USA).
Twenty-four-h representative wastewater and reclaimed water samples were collected from different positions of several municipal wastewater treatment and reclamation plants in Beijing and Tianjin, China. At the same time, three drinking water samples (D9-D11) were collected from the finished water tanks of different cities, and eight samples (D1D8) were collected from a pilot system treating source water from the Huangpu River in Shanghai, China, with a combined process (combination of coagulation-sedimentation-sand filtration and ozonation-biological activated carbon filtration). For chlorinated water samples, sodium thiosulfate $(20 \mathrm{mg} /$ $1,000 \mathrm{~mL}$ ) was added to quench chlorine residue. The samples were stored with ice during transportation, delivered to the laboratory as soon as possible, and then filtered through glass fiber filters $(0.7 \mu \mathrm{m})$ to eliminate suspended solids.

The filtered water samples were concentrated and prepared as described by Ma et al. (2012) with some modifications. Briefly, Oasis HLB solid extraction cartridges (6 cc $500 \mathrm{mg}$, Waters, USA) were conditioned before use with $10 \mathrm{~mL}$ of dichloromethane, $10 \mathrm{~mL}$ of acetone, $10 \mathrm{~mL}$ of methanol and $10 \mathrm{~mL}$ of distilled water in succession. $2.5 \mathrm{~L}$ drinking water, $1 \mathrm{~L}$ reclaimed water or $0.075 \mathrm{~L}$ wastewater sample was loaded onto one cartridge, respectively, then dried under a gentle nitrogen flow and eluted with $15 \mathrm{~mL}$ of acetone. The eluate was dried using nitrogen gas and the dried residues were reconstituted with $25 \mu \mathrm{L}$ dimethylsulfoxide (DMSO). The extracts were stored in the dark at $-20^{\circ} \mathrm{C}$ before the umu test.

The modified microplate method developed by Oda et al. (2004) was used for the ити test. $2 \mu \mathrm{L}$ of water sample extracts or chemicals was added to the exponentially growing tester strain culture $(98 \mu \mathrm{L})$, and the mixture was incubated at $37^{\circ} \mathrm{C}$ for $2 \mathrm{~h}$. Subsequently, in the step of detecting $\beta$-galactosidase activity, $10 \mu \mathrm{L}$ of the culture was transferred to a microplate with either the conventional extraction system $(90 \mu \mathrm{L}$ Z-buffer and $50 \mu \mathrm{L}$ of $0.1 \%$ SDS) (Oda et al. 2004) or B. M. Mix $(50 \mu \mathrm{L})$. The enzymatic reaction was started by the addition of $10 \mu \mathrm{L}$ of $4 \mathrm{mg} / \mathrm{mL}$ CPRG, and incubated for $20 \mathrm{~min}$ at $37^{\circ} \mathrm{C}$, and

Table 1 Effects of the concentration of SDS and adding volume of B. M. Mix on induction of umuC gene expression by 4-NQO

\begin{tabular}{|c|c|c|c|c|c|c|}
\hline \multirow[t]{2}{*}{ 4-NQO $(\mu \mathrm{g} / \mathrm{mL})$} & \multicolumn{2}{|l|}{0} & \multicolumn{2}{|l|}{0.625} & \multicolumn{2}{|l|}{1.25} \\
\hline & $\mathrm{RGA} \pm \mathrm{SD}$ & $\mathrm{IR}^{\mathrm{a}}$ & $\mathrm{RGA} \pm \mathrm{SD}$ & IR & $\mathrm{RGA} \pm \mathrm{SD}$ & IR \\
\hline $0.1 \%$ SDS & $0.79 \pm 0.02$ & 1.00 & $4.91 \pm 0.31$ & 6.23 & $12.10 \pm 1.15$ & 15.34 \\
\hline $1 \% \mathrm{SDS}$ & $0.63 \pm 0.02$ & 1.00 & $4.67 \pm 0.10$ & 7.39 & $9.65 \pm 1.64$ & 15.26 \\
\hline $5 \% \mathrm{SDS}$ & $0.39 \pm 0.01$ & 1.00 & $3.11 \pm 0.18$ & 7.93 & $5.50 \pm 0.55$ & 13.99 \\
\hline $10 \mu \mathrm{L}$ B. M. Mix & $0.24 \pm 0.01$ & 1.00 & $1.45 \pm 0.03$ & 6.11 & $2.20 \pm 0.27$ & 9.25 \\
\hline $50 \mu \mathrm{L}$ B. M. Mix & $0.61 \pm 0.02$ & 1.00 & $6.92 \pm 0.46$ & 11.33 & $10.28 \pm 1.19$ & 16.82 \\
\hline $90 \mu \mathrm{L}$ B. M. Mix & $0.64 \pm 0.04$ & 1.00 & $7.02 \pm 0.49$ & 10.98 & $10.29 \pm 0.85$ & 16.10 \\
\hline
\end{tabular}

${ }^{\text {a }}$ IR The induction ratio (IR) was defined as the mean value of RGAs (adjusted $\mathrm{A}_{570} / \mathrm{A}_{595}$ ) at the tested doses divided by their values in the control 


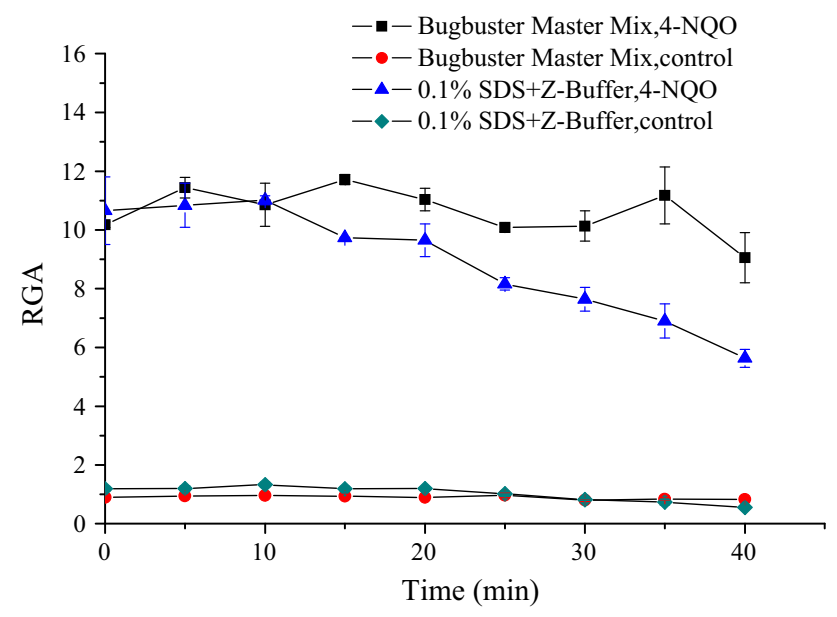

Fig. 1 Effects of time of B. M. Mix and SDS treatment on induction of $u m u C$ gene expression by 4-NQO. (Tester cells were treated with $0.625 \mu \mathrm{g} / \mathrm{mL}$ of $4-\mathrm{NQO}$ and in order to check the stability of $\beta$ galactosidase in SDS + Z-buffer lytic solution and B. M. Mix during the lytic period, CPRG was added to the cell-reaction mixture after various periods of lysis, and the $\beta$-galactosidase activity was assayed. Bar in figure represents standard deviation)

was stopped by adding $1 \mathrm{M} \mathrm{Na}_{2} \mathrm{CO}_{3}(100 \mu \mathrm{L})$. Absorbance at $570 \mathrm{~nm}\left(\mathrm{~A}_{570}\right)$ was read on the microplate reader to estimate the relative $\beta$-galactosidase activity (RGA). In this assay, DMSO was employed as a solvent control and a twofold increase in RGA above the control levels was estimated as positive. The results represented means of triplicate determinations. The genotoxicity of water sample was standardized to an equivalent 4-NQO or 2-AA concentration (4-NQO EQ or 2-AA EQ) (Wu et al. 2010).

\section{Results and Discussion}

In the enzyme assay step of the ити test, chemical cell disruption using proper detergents is vital for releasing $\beta$-galactosidase from bacterial cells (Quillardet and Hofnung 1985; Whong et al. 1986), and in the modified итиmicroplate test system of Oda et al. (2004) a combination of $90 \mu \mathrm{L} \mathrm{Z}$-buffer and $50 \mu \mathrm{L} 0.1 \%$ SDS is used to lyse cells. Table 1 shows the $\beta$-galactosidase activities and induction ratio (IR) values under different enzyme extraction conditions with $4-\mathrm{NQO}(0.625$ or $1.25 \mu \mathrm{g} / \mathrm{mL})$ as the positive marker. The detected $\beta$-galactosidase activity decreased with the increase of SDS concentration, showing that the use of SDS could lead to denaturation of $\beta$ galactosidase. When B. M. Mix was used, on the other hand, the $\beta$-galactosidase activity increased with the increase of B. M. Mix volume from 10 to $50 \mu \mathrm{L}$. However, further increase of B. M. Mix volume to $90 \mu \mathrm{L}$ did not lead to the increase of $\beta$-galactosidase activity. Thus, the optimum application volume of B. M. Mix was determined to be $50 \mu \mathrm{L}$. The B. M. Mix system exhibited significantly higher IR values (7.02) than 4.91 of the conventional one employing SDS, particularly for the low exposure concentration of 4-NQO $(0.625 \mu \mathrm{g} / \mathrm{mL})$.

The effects of both enzyme extraction agents on the stability of $\beta$-galactosidase were compared (Fig. 1). For the SDS treatment system, the $\beta$-galactosidase activity was relatively stable for the first $10 \mathrm{~min}$, but then decreased gradually, ending up with a decrease of $47 \%$ after 40-min treatment, which was in accordance with previous reports (Demeo et al. 1988; El Mzibri et al. 1996; Whong et al. 1986). For the B. M. Mix treatment system, on the other hand, the $\beta$-galactosidase activity was almost constant over a period of $40 \mathrm{~min}$. It has been reported that the detergent mixture in B. M. Mix was capable of cell wall perforation without denaturing proteins (Novagen ${ }^{\circledR}$ and Calbiochem ${ }^{\circledR}$ 2004). Therefore, B. M. Mix was favorable in terms of maintaining the stability of $\beta$-galactosidase, which was important for ensuring the measurement accuracy of the ити test.

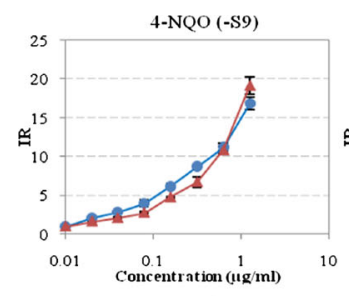

2-AA (+S9)
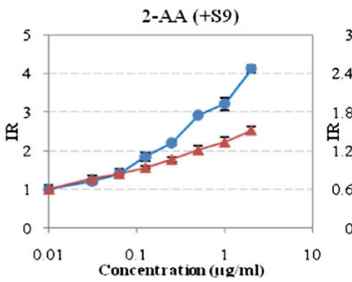

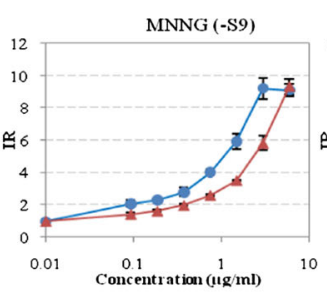

$\mathrm{B}[\alpha] \mathrm{P}(+\mathrm{S} 9)$

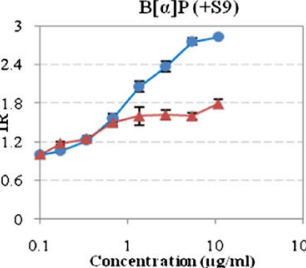

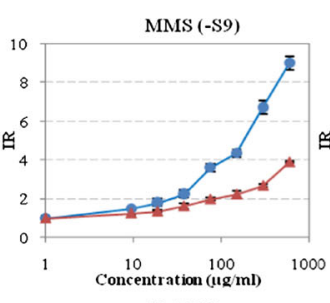

IQ (+S9)

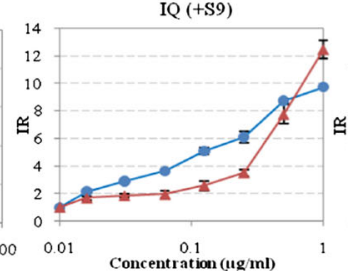

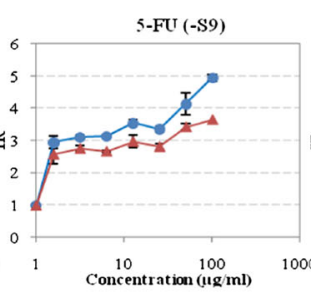

Trp-P-1 (+S9)

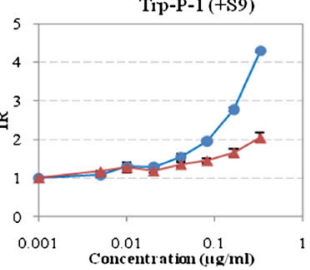

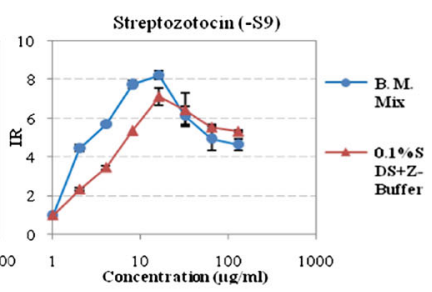

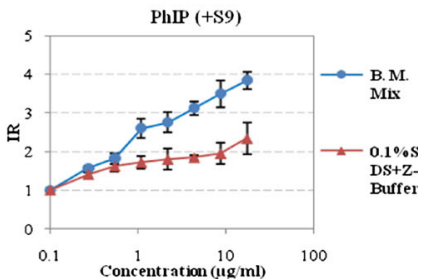

Fig. 2 Effects of B. M. Mix and SDS treatment on induction of $и т и \mathrm{C}$ gene expression by various chemicals 
Table 2 The effects of B. M. Mix and SDS treatment on induction of $u m u$ C gene expression by water samples

\begin{tabular}{|c|c|c|c|c|c|c|c|c|c|}
\hline \multicolumn{2}{|c|}{ Samples } & \multicolumn{4}{|c|}{ B. M. Mix } & \multicolumn{4}{|c|}{$0.1 \%$ SDS + Z-Buffer } \\
\hline & & $\begin{array}{l}\text { Positive/ } \\
\text { negative } \\
(\mathrm{mL})^{\mathrm{a}}\end{array}$ & $\begin{array}{l}\text { SOSIA }^{b} \\
(\mathrm{IR} / \mathrm{mL})\end{array}$ & $\begin{array}{l}\text { 4-NQO or } \\
2-\mathrm{AA} E Q \\
(\mu \mathrm{g} / \mathrm{L})\end{array}$ & $\begin{array}{l}\text { Carcinogenic } \\
\operatorname{risk}^{\mathrm{c}}\left(\times 10^{-6}\right)\end{array}$ & $\begin{array}{l}\text { Positive/ } \\
\text { negative } \\
(\mathrm{mL})^{\mathrm{a}}\end{array}$ & $\begin{array}{l}\text { SOSIA }^{b} \\
(\mathrm{IR} / \mathrm{mL})\end{array}$ & $\begin{array}{l}\text { 4-NQO or } \\
2-\mathrm{AA} \text { EQ } \\
(\mu \mathrm{g} / \mathrm{L})\end{array}$ & $\begin{array}{l}\text { Carcinogenic } \\
\operatorname{risk}^{\mathrm{c}}\left(\times 10^{-6}\right)\end{array}$ \\
\hline \multirow[t]{11}{*}{$\mathrm{D}$} & D1 & $-(200)$ & - & - & - & $-(200)$ & - & - & - \\
\hline & D2 & $-(200)$ & - & - & - & $-(200)$ & - & - & - \\
\hline & D3 & $-(200)$ & 0.0013 & 0.0053 & 0.0554 & $-(200)$ & - & - & - \\
\hline & D4 & $-(200)$ & 0.0012 & 0.0046 & 0.0486 & $-(200)$ & - & - & - \\
\hline & D5 & $-(200)$ & 0.0017 & 0.0062 & 0.0654 & $-(200)$ & - & - & - \\
\hline & D6 & $-(200)$ & 0.0010 & 0.0038 & 0.0399 & $-(200)$ & - & - & - \\
\hline & D7 & $-(200)$ & 0.0012 & 0.0044 & 0.0468 & $-(200)$ & - & - & - \\
\hline & D8 & $-(200)$ & 0.0008 & 0.0028 & 0.0290 & $-(200)$ & - & - & - \\
\hline & D9 & $+(100)$ & 0.0110 & 0.0627 & 0.6606 & $-(200)$ & 0.0019 & 0.0111 & 0.1172 \\
\hline & D10 & $+(25)$ & 0.0488 & 0.2774 & 2.9245 & $-(200)$ & 0.0065 & 0.0375 & 0.3949 \\
\hline & D11 & $-(125)$ & 0.0035 & 0.0199 & 0.2096 & $-(125)$ & 0.0024 & 0.0129 & 0.1355 \\
\hline \multirow[t]{17}{*}{$\mathrm{R}$} & $\mathrm{R} 1$ & $+(20)$ & 0.0858 & 0.5645 & & $+(40)$ & 0.0294 & 0.3698 & \\
\hline & $\mathrm{R} 2$ & $-(80)$ & 0.0035 & 0.0230 & & $-(80)$ & - & - & \\
\hline & R3 & $-(80)$ & 0.0033 & 0.0216 & & $-(80)$ & - & - & \\
\hline & R1 (+S9) & $+(20)$ & 0.0910 & 7.3344 & & $+(40)$ & 0.0888 & 7.4363 & \\
\hline & $\mathrm{R} 2(+\mathrm{S} 9)$ & $-(80)$ & 0.0027 & 0.2176 & & $-(80)$ & - & - & \\
\hline & R3 (+S9) & $-(80)$ & - & - & & $-(80)$ & - & - & \\
\hline & $\mathrm{R} 4$ & $-(40)$ & 0.0287 & 0.2148 & & $-(40)$ & 0.0053 & 0.1292 & \\
\hline & R5 & $+(20)$ & 0.0802 & 0.6003 & & $-(40)$ & 0.0117 & 0.2868 & \\
\hline & R6 & $+(40)$ & 0.0264 & 0.1437 & & $+(80)$ & 0.0116 & 0.1420 & \\
\hline & $\mathrm{R} 7$ & $-(80)$ & 0.0157 & 0.0853 & & $-(80)$ & - & - & \\
\hline & $\mathrm{R} 8$ & $+(40)$ & 0.0252 & 0.1372 & & $-(80)$ & 0.0058 & 0.0703 & \\
\hline & R9 & $+(80)$ & 0.0218 & 0.1191 & & $-(80)$ & 0.0015 & 0.0181 & \\
\hline & $\mathrm{R} 10$ & $+(80)$ & 0.0147 & 0.0801 & & $-(80)$ & 0.0027 & 0.0327 & \\
\hline & R11 & $-(80)$ & - & - & & $-(80)$ & - & - & \\
\hline & $\mathrm{R} 12$ & $+(40)$ & 0.0296 & 0.1616 & & $-(80)$ & 0.0033 & 0.0403 & \\
\hline & $\mathrm{R} 13$ & $+(40)$ & 0.0366 & 0.1993 & & $-(80)$ & 0.0064 & 0.0775 & \\
\hline & R14 & $+(20)$ & 0.0782 & 0.4265 & & $-(80)$ & 0.0123 & 0.1499 & \\
\hline \multirow[t]{3}{*}{ W } & W1 & $+(0.75)$ & 2.0120 & 15.0553 & & $+(1.5)$ & 0.5803 & 14.1977 & \\
\hline & $\mathrm{W} 1(+\mathrm{S} 9)$ & $+(1.5)$ & 1.5642 & 23.6175 & & $+(1.5)$ & 0.8843 & 17.0094 & \\
\hline & W2 & $-(2)$ & 0.5271 & 3.8626 & & $-(2)$ & 0.1854 & 3.3283 & \\
\hline
\end{tabular}

$D$ drinking water, $R$ reclaimed water, $W$ wastewater

a Positive/negative: "+"- positive;"-"-negative; the value in bracket represents the first volume (mL) detected showing positive response or the maximum volume tested with negative result

b SOSIA: the SOS-inducing activity (SOSIA) was defined as the slope of the linear portion of the dose-response curve and was calculated by regression analysis

${ }^{c}$ Carcinogenic risk: the carcinogenic risk of detected samples was calculated according to eq: carcinogenic risk $\left(\times 10^{-6}\right)=4-\mathrm{NQO}$ EQ of the sample $\times 0.001 \times 0.369 \times 2 \times 10^{6} / 70$ (Zhu et al. 2008)

The performance of the two extraction reagents in detecting итиC gene expressions induced by 10 chemicals in the presence and absence of S9 mix was compared as shown in Fig. 2. All the chemicals exhibited an increase of RGA in a dose-dependent fashion. In comparison with the SDS treatment, the use of B. M. Mix generated stronger genotoxic responses for 4-NQO, MNNG, MMS, 5-FU, and streptozotocin without S9 mix, and 2-AA, B[ $[\alpha]$, IQ, Trp-P-1, and PhIP with S9 mix. Positive results were obtained at much lower exposure concentrations for compounds like 4-NQO, MNNG, MMS, 5-FU, and streptozotocin (Fig. 2). 
Table 3 Genotoxic potencies of reclaimed water samples in the presence and absence of S9 mix

\begin{tabular}{|c|c|c|c|c|c|c|}
\hline \multirow[t]{2}{*}{ Samples } & \multicolumn{3}{|l|}{$-\mathrm{S} 9$} & \multicolumn{3}{|l|}{$+\mathrm{S} 9$} \\
\hline & Positive/negative $^{\mathrm{a}}$ & SOSIA (IR/mL) & 4-NQO EQ $(\mu \mathrm{g} / \mathrm{L})$ & Positive/negative $\mathrm{a}^{\mathrm{a}}$ & SOSIA (IR/mL) & 2 2-AA EQ $(\mu \mathrm{g} / \mathrm{L})$ \\
\hline $\mathrm{G}$ influent & $+(10)$ & 0.1510 & 0.7334 & $+(10)$ & 0.1373 & 10.1704 \\
\hline G effluent & $+(10)$ & 0.1259 & 0.6115 & $+(20)$ & 0.1113 & 8.2444 \\
\hline $\mathrm{J}$ influent & $+(10)$ & 0.1388 & 0.6741 & $+(10)$ & 0.1434 & 10.6222 \\
\hline $\mathrm{J}$ effluent & $+(80)$ & 0.0195 & 0.0947 & $-(80)$ & 0.0099 & 0.7333 \\
\hline Q influent & $+(40)$ & 0.0392 & 0.1904 & $+(40)$ & 0.0296 & 2.1926 \\
\hline Q effluent & $-(80)$ & 0.0125 & 0.0607 & $-(80)$ & 0.0044 & 0.3259 \\
\hline $\mathrm{JZ}$ influent & $+(40)$ & 0.0256 & 0.1243 & $+(40)$ & 0.0230 & 1.7037 \\
\hline JZ effluent & $+(40)$ & 0.0335 & 0.1627 & $+(80)$ & 0.0125 & 0.9259 \\
\hline
\end{tabular}

a Positive/negative: "+"-positive;"-"-negative; the value in bracket represents the first volume $(\mathrm{mL})$ or concentration $(\mu \mathrm{g} / \mathrm{mL}) \mathrm{detected}$ showing positive response or the maximum volume with negative result

G, J and Q RWTPs are located in Beijing and JZ RWTP is located in Tianjin

The performance of the two extraction reagents in detecting $и т и \mathrm{C}$ gene expressions induced by environmental samples in the presence and absence of S9 mix was further compared as shown in Table 2. Among the twenty-seven samples, twelve samples (two drinking water, nine reclaimed water, and one wastewater samples) elicited positive responses when using the B. M. Mix treatment, however, only three samples (two reclaimed water and one wastewater samples) showed positive responses using the SDS treatment. The three positive responses observed in the umu test using the SDS extraction system were also caught in that using the B. M. Mix system. At the same time, the sample volumes required for the positive results were lower in the $\mathrm{B}$. M. Mix treated tests (Table 2). It should be noted that one drinking water sample (D10) exhibited a high carcinogenic risk, which was over the control standard $\left(10^{-6}\right)$ recommended by EPA (2006). On the other hand, even for those without positive response, such as D3-D8 (drinking water), R2 and R3 (reclaimed water), a linear dose-response relationship between the genotoxic induction ratios and their corresponding original volumes was observed in the tests using B. M. Mix, making it possible to calculate the 4-NQO or 2-AA equivalents of the samples (Table 2), which is helpful for the risk management of drinking water (Zhu et al. 2008) and in comparing the changes in genotoxicity of reclaimed water (Zhang and Zhao 2013). Both the assays of genotoxins and water samples showed B. M. Mix could increase the sensitivity of umu test. In addition to the difference of $\beta$-galactosidase's stability in both reagents, such an improvement could be further explained by the difference in cell lytic ability between the two systems. According to a previous study (De Mey et al. 2008), the use of SDS could result in poor protein recovery, while B. M. Mix was found to be one of the most reliable methods for extracting protein from $E$. coli whole cells and was further recommended as the cell disruption method for proteomic analysis of Paenibacillus sp. (Ganesh and Lin 2011; Chambers 2002).

As an application, the genotoxicity of the influent and effluent of four reclaimed water treatment plants (RWTPs) was evaluated using B. M. Mix as the lytic reagent. The influent of G RWTP exhibited the highest genotoxicity, whereas the effluent of Q RWTP the lowest without S9 activation. Seven of the eight samples, particularly the three effluent samples, exhibited decreased SOS-induction activity (SOSIA) values under the addition of S9 mix, showing that the genotoxins in these samples could be inactivated by $\mathrm{S} 9$ enzymes. Of the four RWTPs investigated, G plant, using the traditional coagulation-sand filtration technology, showed the lowest efficiency in removing the genotoxicity from its influent, while both $\mathrm{Q}$ and $\mathbf{J}$ plants, applying ozonation, exhibited satisfactory genotoxicity removal performance. Ozone as a strong oxidant has exhibited high efficiency in decreasing genotoxicity from wastewater in previous studies (Misik et al. 2011; Cao et al. 2009). The coagulation-microfiltrationchlorination process adopted by JZ RWTP could effectively remove $\mathrm{UV}_{254}$ and DOC (data not shown), but the genotoxic potential in its final effluent increased by $30.86 \%$ compared with that of the influent (Table 3). The increased genotoxicity might be related with the high residual chlorine in the effluent $(0.57 \mathrm{mg} / \mathrm{L})$. In fact, chlorination disinfection byproducts, such as chlorinated aromatic hydrocarbons and halogenated alkanes, have been reported to contribute to the increase of genotoxicity after chlorination (Shen et al. 2003).

In conclusion, comparing with the conventional reagent, B. M. Mix could maintain the stability of $\beta$-galactosidase, which was favorable for ensuring measurement accuracy. 
More important, the sensitivity of the $u m u$-microplate test could be markedly improved by adopting B. M. Mix as the enzyme extraction reagent. Ozonation was found to be effective in removing genotoxicity from wastewater, while chlorination of the reclaimed water led to the increase of genotoxicity. Thus, careful consideration should be taken in choosing the treatment and disinfection technologies for wastewater reclamation to reduce environmental risks.

Acknowledgments This work was funded by the Science Fund for the Creative Research Groups of China (No. 51221892) and the Ministry of Science and Technology, Peoples Republic of China (2013DFG50150).

Conflict of interest None declared.

\section{References}

Cao N, Yang M, Zhang Y et al (2009) Evaluation of wastewater reclamation technologies based on in vitro and in vivo bioassays. Sci Total Environ 407:1588-1597

Chambers SP (2002) High-throughput protein expression for the postgenomic era. Drug Discov Today 7:759-765

De Mey M, Lequeux GJ, Maertens J et al (2008) Comparison of protein quantification and extraction methods suitable for $E$. coli cultures. Biologicals 36:198-202

Demeo MP, Miribel V, Botta A et al (1988) Applicability of the SOS chromotest to detect urinary mutagenicity caused by smoking. Mutagenesis 3:277-283

Deutsches Institut für Normung (DIN) (1996) 38415-3: German standard methods for the examination of water, waste water and sludge — sub-animal testing (group T) - part 3: determination of the genotoxic potential of water with the ити-test (T 3)

Dizer H, Wittekindt E, Fischer B et al (2002) The cytotoxic and genotoxic potential of surface water and wastewater effluents as determined by bioluminescence, ити-assays and selected biomarkers. Chemosphere 46:225-233

El Mzibri M, DeMeo MP, Laget M et al (1996) The Salmonella sulAtest: a new in vitro system to detect genotoxins. Mutat Res 369:195-208

Ganesh A, Lin J (2011) Comparisons of protein extraction procedures and quantification methods for the proteomic analysis of Grampositive Paenibacillus sp. strain D9. World J Microb Biot 27:1669-1678

Grabski A, McCormick M, Mierendorf R (1999) BugBuster ${ }^{\mathrm{TM}}$ and Benzonase $^{\circledR}$ : the clear solutions to simple, efficient extraction of E. coli proteins. Innovations 10:17-19

Grage K, Peters V, Rehm BHA (2011) Recombinant protein production by In vivo polymer inclusion display. Appl Environ Microbiol 77:6706-6709

Hamer B, Bihari N, Reifferscheid G et al (2000) Evaluation of the SOS/umu-test post-treatment assay for the detection of genotoxic activities of pure compounds and complex environmental mixtures. Mutat Res 466:161-171

ISO (2000) 13829: Water quality—determination of the genotoxicity of water and waste water using the $u m u$-test

Ma FJ, Yuan GX, Meng LP et al (2012) Contributions of flumequine and nitroarenes to the genotoxicity of river and ground waters. Chemosphere 88:476-483

Michel B (2005) After 30 years of study, the bacterial SOS response still surprises us. PLoS Biol 3:1174-1176

Miller JH (1972) Experiments in molecular genetics. Cold Spring Harbor Press, Cold Spring Harbor, NY

Misik M, Knasmueller S, Ferk F et al (2011) Impact of ozonation on the genotoxic activity of tertiary treated municipal wastewater. Water Res 45:3681-3691

Monarca S, Zani C, Richardson SD et al (2004) A new approach to evaluating the toxicity of genotoxicity of disinfected drinking water. Water Res 38:3809-3819

Novagen ${ }^{\circledR}$ and Calbiochem ${ }^{\circledR}$ (2004) Sample preparation-tools for protein research. Merck Biosciences Ltd., Darmstadt, Germany, pp 5-10

Novagen ${ }^{\circledR}$ and Calbiochem ${ }^{\circledR}$ (2006) Sample preparation-tools for protein research, 2nd edn. Merck Biosciences Ltd., Darmstadt, Germany, p 16

Oda Y, Nakamura S, Oki I et al (1985) Evaluation of the new system (umu-test) for the detection of environmental mutagens and carcinogens. Mutat Res 147:219-229

Oda Y, Funasaka K, Kitano M et al (2004) Use of a high-throughput ити-microplate test system for rapid detection of genotoxicity produced by mutagenic carcinogens and airborne particulate matter. Environ Mol Mutagen 43:10-19

Ohe T, Watanabe T, Wakabayashi K (2004) Mutagens in surface waters: a review. Mutat Res 567:109-149

Quillardet P, Hofnung M (1985) The SOS chromotest, a colorimetric bacterial assay for genotoxins: procedures. Mutat Res 147:65-78

Shen L, Wu JY, Lin GF et al (2003) The mutagenic potentials of tap water samples in Shanghai. Chemosphere 52:1641-1646

US Environmental Protection Agency (EPA) (2006) EPA Superfund Record of Decision: Scorpio Recycling, Inc. (EPA ID: PRD987376662). http://www.epa.gov/superfund/sites/rods/full text/r2006020001432.pdf. Accessed 21 Nov 2013

Whong WZ, Wen YF, Stewart J et al (1986) Validation of the SOS/ umu test with mutagenic complex mixtures. Mutat Res 175:139-144

Wu QY, Li Y, Hu HY et al (2010) Reduced effect of bromide on the genotoxicity in secondary effluent of a municipal wastewater treatment plant during chlorination. Environ Sci Technol 44:4924-4929

Zhang X, Zhao X (2013) Ecotoxicity assessment of artificial groundwater recharge with reclaimed water: a pilot-scale study. Bull Environ Contam Toxicol 91:499-502

Zhu Z, Gu W, An W et al (2008) Carcinogen risk assessment of drinking water based on genotoxic activities using SOS/umu test. Asian J Ecotoxicol 3:363-369 